\title{
Effect of vehicle emissions on the morphological and physiological changes of Taraxacum officinale web
}

\author{
I. Chemerys ${ }^{1}$, O. Myslyuk ${ }^{1}$, V. Chemerys ${ }^{2}$ \\ ${ }^{1}$ Cherkasy State Technological University, Shevchenko blvd. 460, UA-18006, Cherkasy, Ukraine \\ ${ }^{2}$ Vilnius Gediminas Technical University, Sauletekio al. 11, LT-10223, Vilnius, Lithuania \\ ORCHID ID: https://orcid.org/0000-0002-0664-8508; https://orcid.org/0000-0003-0401-9836; \\ https://orcid.org/0000-0002-4258-4687
}

E-mail: ichemerys@ukr.net, omyslyuk13@gmail.com, valeriia.chemerys@vgtu.It

Received 01.01.2020 Accepted 01.02.2020

\begin{abstract}
Road transport is one of the main pollutants of atmospheric air and soil in modern cities, therefore, an important issue is the comprehensive diagnosis of the state of the environment, which can be carried out by phytoindication methods, and which make it possible to comprehensively assess the environmental risks of the roadside environment for living organisms. The article analyzes the morphological and physiological changes of Taraxacum officinale Web. that occurred under the influence of vehicle emissions. For research, we chose a territory with significant aerotechnogenic loads due to both stationary sources of pollution and traffic flows - the southwestern district of the city for the analysis of plants, the following indicators were studied: mass of plants; leaf length; proportion of altered forms; ascorbic acid content; chlorophyll concentration. In the study, biometric, spectrophotometric and statistical methods were used. The results of the studies showed that in all plants inhibition of parameters was observed in comparison with the control samples. An analysis of the tightness of the relationship between the morphophysiological parameters of the plant, the traffic intensity and the distance from the road were influenced by the average mass of plants ( $r=0.97)$ in the area with heavy traffic, the content of chlorophyll $(r=0.92)$ in the same area, the proportion of altered forms $(r=-0.94)$. The correlation coefficient of the proportion of altered forms is negative, since the number of altered forms decreases with increasing distance from the road. It was found, that content of chlorophyll depends on traffic intensity and the distance from the road (the correlation coefficient ranged from 0.88-0.97). Indicators of leaf length and vitamin C content turned out to be less informative, since there is no clear relationship between these indicators and distance from the road $(r=0.54)$, although with an increase in the distance from the highway, there is a slight increase in leaf length, but the content of vitamin $C$ did not show depending on the distance to the road. The further developments lies in the refinement of the information content of such an indicator as the content of ascorbic acid in order to use it to indicate invisible changes in the vegetation cover.
\end{abstract}

Key words: Motor transport; Plant mass; Leaf length; Modified forms; Ascorbic acid; Chlorophyll

\section{Introduction}

One of the main threats for the development of biodiversity in Ukraine is the impact of transport, which is manifested both in the air and soil pollution, and in the fragmentation of the landscape. Air pollution in urban ecosystems is increasing annually; especially the contribution of road transport is rising and the proportion of vehicle emissions can be up to 70-90\% of the total air emissions. Over the past decade, Ukraine has significantly increased the number of vehicles that turned the latter into a powerful and dangerous source of aero-genic pollution. The situation with constant pollution, which has developed in big cities, tends to deteriorate. Therefore, there is the necessity for the diagnosis of the state of the environment, which can be carried out by physical and chemical methods, and phyto-indication techniques. Phyto-indication, in contrast to the physical and chemical methods that allow to qualitatively and quantitatively characterize the effects of factors, makes it possible to detect biological effects of environmental pollution, therefore while assessing the state of the environment physical, it is urgent to use chemical and bio-indication methods. Phytoindication has several advantages, for example, in the case where it is easy to measure the factor but it is difficult to evaluate the combined influence of factors on wildlife as living organisms respond differently to different concentrations of the compounds, the effects of joint or sequential action can be antagonistic, additive and synergistic. The vegetation cover is quite sensitive to the action of pollutants contained in vehicle emissions and can be used as a phyto-indicator, which gives the opportunity to evaluate the ecological state of the urban environment. Therefore, the negative impact of transport on the environment can be estimated by plants condition. It is the studies of the relationship of plants and urban environment of today are not fully investigated, though active research developments devoted to phyto-monitoring as one of the method for assessing the quality of the environment are conducted (Markert et al., 2012). The purpose of this study is to clarify the phyto-indicative possibilities of dandelion medicinal (Taraxacum officinale Web.). The main objectives of the work are the analysis of changes in the morphological and physiological characteristics of plants under the influence of emissions from motor vehicles with the purpose to diagnose the state of a complex urban ecosystem. 
The object of the study is dandelion medicinal-a perennial herb of the family Asteraceae, as it is common in urban areas, often found in a roadside vegetation cover. Hypothesis of the study is the development of the morphological and physiological changes in the plants under the influence of vehicle emissions and the possibility of their use in phytomonitoring. The novelty of the study is a comprehensive analysis of the changes in dandelion medicinal in a roadside environment and evaluation of the suitability of individual indicators for phyto-monitoring.

The industrialization and human activities intensify the emission of various pollutants into the environment and introduce various harmful substances into the atmosphere. Oxides sulfur and nitrogen compounds, and heavy metals-cadmium, lead, mercury, zinc, copper, cobalt, nickel appear to be the main atmospheric pollutants in urban areas today (Kolesnikov et al., 2001; Tan et al., 2014; Aksu, 2015). Studies have shown a close correlation between traffic intensity and the accumulation of metals in the soil, with maximum concentrations observed at a distance of $0-1 \mathrm{~m}$ and $90-100 \mathrm{~m}$ off the road, the content of heavy metals corresponded to the background level (Dániel et al., 1997; Zhang et al., 2012; Šeda M. et al., 2017). However, not only heavy metals have a phytotoxic effect on plants. Petroleum hydrocarbons and nitrogen oxides have a quite damaging effect as well (Bell et al., 2011; Labuzova et al., 2016). The urgent environmental problem of our time is the increase in the area of salinization of urban soils. The accumulation of salts in the surface layers of soils is manifested in changes in the growth and development of plants, is affected by the structure and functioning of the photosynthetic apparatus of plants, which ultimately causes a suppression of growth, development and productivity of plants, affecting soil microorganisms (Gupta \& Huang, 2014). It has been shown that salt in roadside soils can increase the availability of nitrogen from NOx for plants, which increases phytotoxicity (Spencer et al., 1988).

Unlike air and water, soil experiences the greatest impact of the urban pressure, quickly absorbs pollutants and transforms them very slowly. Condition of urban soils determines the ecological situation in the city as a whole. The soil in the urban environment is a kind of a powerful filter, which, together with the plants absorbs and partially neutralizes toxic emissions. The city territory is a geochemical anomaly of polyelement composition. The source of man-made habitats within the housing and industrial agglomerations is enterprises and highways, to the placements of which, as a rule, tend areas with the contaminated soil. Under the influence of exhaust gases $\mathrm{Pb}, \mathrm{Zn}, \mathrm{Cu}, \mathrm{Ni}$ fall in the soil, whose concentration sometimes reaches tens of MAC, especially $\mathrm{Pb}$. Toxic elements spread in the soil of the roadside and on the plants at a distance of around 100 meters. The creation of the anthropogenic carbonate sorption and biogenic geochemical barriers in the roadside landscapes contributes to the localization of these elements. The nature of the profile distribution is influenced by the complex of soil factors: particle size distribution, $\mathrm{pH}$ and others. The intensity of road traffic, ditches on roadsides and terrain conditions affect the distribution of heavy metals in the soil of roadsides. (Mikalayuene\& Jakučionytè, 2011).

The soil contaminated with the heavy metals appears to be hardly suitable or uninhabitable for most living organisms. Even if the soil does not become lifeless, the biocenoses formed in it are characterized by a low biomass, a low rate of biological processes, narrow species composition, weak resistance. It is known that the condition of the soil environment optimal for microorganisms and higher plants are optimal for enzymatic activity. Soil microorganisms react quickly on the change of the ecological functions and soil condition, which is reflected in the biochemical activity (Garcla-Gil et al., 2000; Nagajyoti et al., 2010). The sterilizing effect of different pollutants leads to the loss of sensitive species of microorganisms, microbial cenoses disintegration, loss of biochemical activity of the soil and destruction of microorganisms leads to the degradation of ecosystems (Wilson et al., 2008).

The content of photosynthetic pigments characterizes the potential ability of plants and there is a direct relationship between the content of pigments and plant damage. The higher chlorophyll a content is an indicator of a high potential rate of photosynthesis. Also one of the reasons for the destruction of chlorophyll is the activation by the pollutants of a lipid peroxidation of chloroplast biological membrane. Chlorophyll a, cartions are more sensitive to aero-toxicants, chlorophyll $b$ is less sensitive. The nature of the effect of aerosolutants on photosynthesis was studied by Chemerys, 2009; Assadi et al., 2011. A whole series of works is devoted to the study of the use of phytoindication involving woody plants to control air pollution with chlorine and lead, which showed that plants accumulate these elements (Nersisyan \& Hovhannisyan, 2010). It has been shown that trees, in particular, ordinary pine, may not only be an indicators of atmospheric air pollution in urban ecosystems, but also used to indicate agricultural pollution (Tesliyk, 2017). It was found that in the conditions of the city there was a change in the morphological parameters of the leaf blade, namely the length and width (Tyulkova, 2015) as well as changes in color, geometric and structural parameters (Wen-yi \& Chun-kui, 2012), a decrease in area, dry weight, the content of chlorophylls a and b and the content of carotenoids increases (El-Khatib et al., 2016; Bessonova \& Ponomaryova, 2017). It was shown that the content of water-soluble antioxidants in plant tissues decreases with an increase in the concentration of $\mathrm{Pb}$ in the soil (Maslennikov et al., 2018).

Ascorbic acid (AsA) is a powerful antioxidant. This property is due to the ability to easily oxidize and form charged radicals. These ions with unpaired electrons are "targets" for the free radicals responsible for the damage to cell membranes and further cell mutation. In addition to antioxidant activity, vitamin $C$ neutralizes many toxic substances and plays a key role in immunological reactions. AsA is one of the markers of the early indication of the plant, which can be used in assessing of the phytomonitoring of the environment. Since the vitamin has protective properties the AsA content in dandelion medicinal leaves was investigated to determine the stress resistance of plants.

AsA increases the chlorophyll content under and without Stessa and is involved in the detoxification of the resulting reactive oxygen species due to abiotic stresses (Dolatabadian \& Jouneghani, 2009). Under the influence of automobile emissions, there is inverse correlation between the content of chlorophyll b and the content of AsA (Raina \& Chand Bala, 2011; Iqbal et al., 2015; Zhou et al., 2018). AsA is one of the universal non-enzymatic antioxidants and a cellular reducing agent; it plays an important role in resistance to oxidative stresses, such as heavy metals (Khan et al., 2011). It accumulates in chloroplasts and is found in all cellular compartments, including the cell wall (Smirnoff \& Wheeler, 2000), has an increased ability to remove $\mathrm{H} 2 \mathrm{O} 2$, which is formed during photosynthetic electron transfer and photo-respiration. The ability of the ascorbate to give electrons allows it to act as an absorber of free radicals (Smirnoff, 2018). Exogenous use of AsA was shown to reduce oxidative damage caused by $\mathrm{Pb}$ toxicity due to increased activity of antioxidant enzymes such as superoxide dismutase, catalase, and glutathione reductase (Lugovskaya et al., 2014; Alamri et al., 2017). An inverse correlation was also observed between the lead content in the soil and antioxidant activity (Samancioglu et al., 2016; Maslennikov et al., 2018). Sometimes AsA can behave like a radical promoter and can form hazardous substances in living systems (Pehlivan, 2017). It should be noted that the symptoms of oxidative stress in resistant plants are less pronounced, and their antioxidant defense system is activated more quickly (Tsandekova et al., 2013).

Taraxacum officinale Web. is actively used in phytoindication biogeochemical studies. The plant grows at different temperatures and meteorological conditions, as well as in places with different levels of pollution, it is easy to identify it, and sampling is easy and economical (Ligocki et al., 2011). Dandelion tolerates a wide range of environmental conditions, and therefore is a biomonitor of 
environmental pollution by metals such as $\mathrm{Cd}, \mathrm{Cr}, \mathrm{Cu}, \mathrm{Fe}, \mathrm{Ni}, \mathrm{Ti}, \mathrm{Mn}, \mathrm{Pb}$ and $\mathrm{Zn}$ (Kabata-Pendias, 2011; Giacomino et al., 2016 Fröhlichová et al., 2018). It has been shown that a plant can accumulate cadmium in vegetative organs, but especially in leaves in the root zone (Kabata-Pendias \& Dudka, 1991). A correlation was also shown between the leaf Cd and the total phenols of the leaf, cichoric and kaftaric acids, which indicates that phenolic metabolites act to protect dandelion from excess Cd (Kováčik et al., 2016); therefore, dandelion is an indicator plant for detecting cadmium pollution (Simon et al., 1996; Ligocki et al., 2011), but cannot be an indicator of pollution by $\mathrm{Mn}$ (Normandin et al., 1999). It is also noted that morphological changes in its vegetative organs are often associated with meteorological factors (Ianovici, 2016), what to consider when analyzing morphometric indicator of vegetative organs. The effect of automobiles on the reproductive activity of $\mathrm{T}$. officinale was also studied, and a positive correlation with the number of seeds and a negative correlation with the mass of seeds were noted (Erofeeva, 2014). The urban environment reduces the genetic diversity of the population of T. officinale (Keane et al., 2005); therefore, it is proposed to use the plant to study environmental tolerance, which serves to establish environmentally acceptable concentrations (EAC) of pollutants for biota (Kudryavs 'ka, \& Dychko, 2014). Today, the question remains unanswered about of using the plant as an indicator of complex pollution not only soil, but also atmospheric. Since different plants show different sensitivity to aero-toxicants due to their anatomical-morphological and physiological-biochemical characteristics the problem of phyto-indicative possibilities of separate widespread plants in urban ecosystems of plants remains unsolved. Therefore the research is devoted to this issue.

\section{Materials and Methods}

The choice of test sites for phyto-indicative research was based on the results of studies of air pollution, soil, snow cover in areas of permanent emissions and calculation of the summary environmental load. Studies have shown that Cherkassy is subjected to a significant aerotechnogenic impact on urban ecosystems of industry and transport, areas of contamination of which overlap and cover the whole territory of the city (Myslyuk et al., 2010). The mapping zoning of the city in terms of summary anthropogenic impact (Figure 1) shows that $48 \%$ of the city (on the map marked in green) can be considered as the one that did not experience a significant aero-technogenic load (Nsum $<50$ tons $/ \mathrm{km}^{2} \cdot$ year), $27 \%$ of the area (marked on the map in pink) experienced moderate pollution to 50 tons $/ \mathrm{km}^{2}$.year $<$ Nsum $<100$ tons $/ \mathrm{km}^{2}$.year), $21 \%$ (on the map marked in yellow)-heavy contamination (100 tons $/ \mathrm{km} 2 \cdot$ year $<$ Nsum $<200$ tons $/ \mathrm{km} 2 \cdot$ year), $4 \%$ of the area (marked on the map in red)-extra contamination in excess of the maximum permissible load (Nsum>200 tons/km2-year). There is an interrelation between the aero-technogenic load and the intensity of traffic, especially on the roads of high technical category, the technological parameters of the roadway.

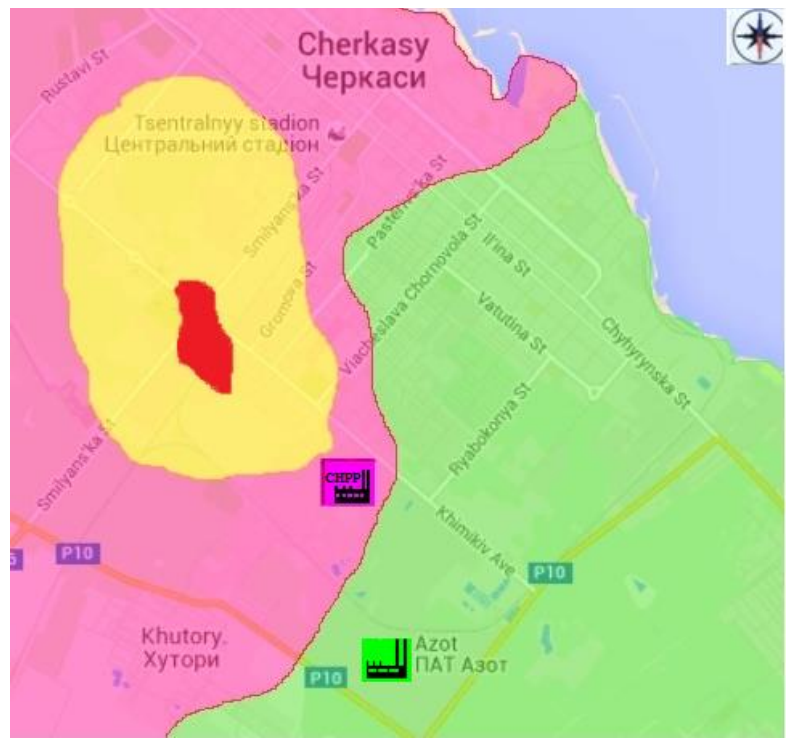

Figure 1. City's polluted zones as for summary ecologic loading.

Aerotechnogenic contamination leads to changes in the physical chemical properties of the soil and its functions. The characteristic signs of anthropogenic transformation of the soil in Cherkassy include a sharp increase compared to natural zonal soils of the spatial heterogeneity of the anionic composition of the soil cover, which is the result of a complex combination of natural processes of selforganization and the varying urbanogenic action, development of the technogenic salinization, carbonization processes, changes in acid-base balance in the direction of alkalizing (Myslyuk et al., $2019 \mathrm{a}, \mathrm{b}$ ).

The area with significant aerotechnogenic loads from both stationary sources of pollution and traffic flows that is the southwest area of the city was chosen for the phyto-indicative research. The model plot № 1 - with heavy traffic (778 \pm 103 units/hour), model plot № 2 - with an average traffic intensity (345 \pm 53 units/hour), model plot №3 - low-intensity traffic ( $43 \pm 11$ units/hour). A control plot was located at a distance of $350 \mathrm{~m}$ from the road without traffic.

The traffic load on the roads was assessed by traffic composition and intensity in the morning, afternoon, evening and night. Counting was carried out in both directions for an hour. Describing the structure of the transport stream the basic categories of vehicles were taken into account: cars, trucks, buses. The structure of the movement is dominated by passenger vehicles - 79\%, trucks - an average of $11 \%$, buses - $10 \%$. The number of buses with petrol and diesel engines constituted $3: 2$, cargo vehicles 9:1. The emissions of harmful substances, the category of substances danger (CSD) and then category of vehicle danger CVD were calculated according to the traffic density by the formulas:

$$
C S D=\left(\frac{M_{i}}{M A C_{i}}\right)^{a_{i}}, m^{3} / s
$$




$$
C V D=\sum_{i=1}^{n} C S D, m^{3} / s
$$

where $\mathrm{Mi}$ - emissions quantity of the i-th contaminant into the atmosphere, $\mathrm{mg} / \mathrm{s}$; MACi - average MAC i-th in the atmosphere of the settlement, $\mathrm{mg} / \mathrm{m}^{3}$; ai - dimensionless constant, which allows to correlate the degree of harmfulness of the i-th substance with harmfulness of sulfur dioxide (the substances $1,2,3$, and 4 hazard class $1.7,1.3,1.0,0.9$, respectively); $n-$ quantity of pollutants emitted on the roads.

Cars Hazard Indicators calculated as shown above are shown in given in Table 1.

Table 1. Ranking of roads according to the category of danger $(x \pm S E, n=10)$.

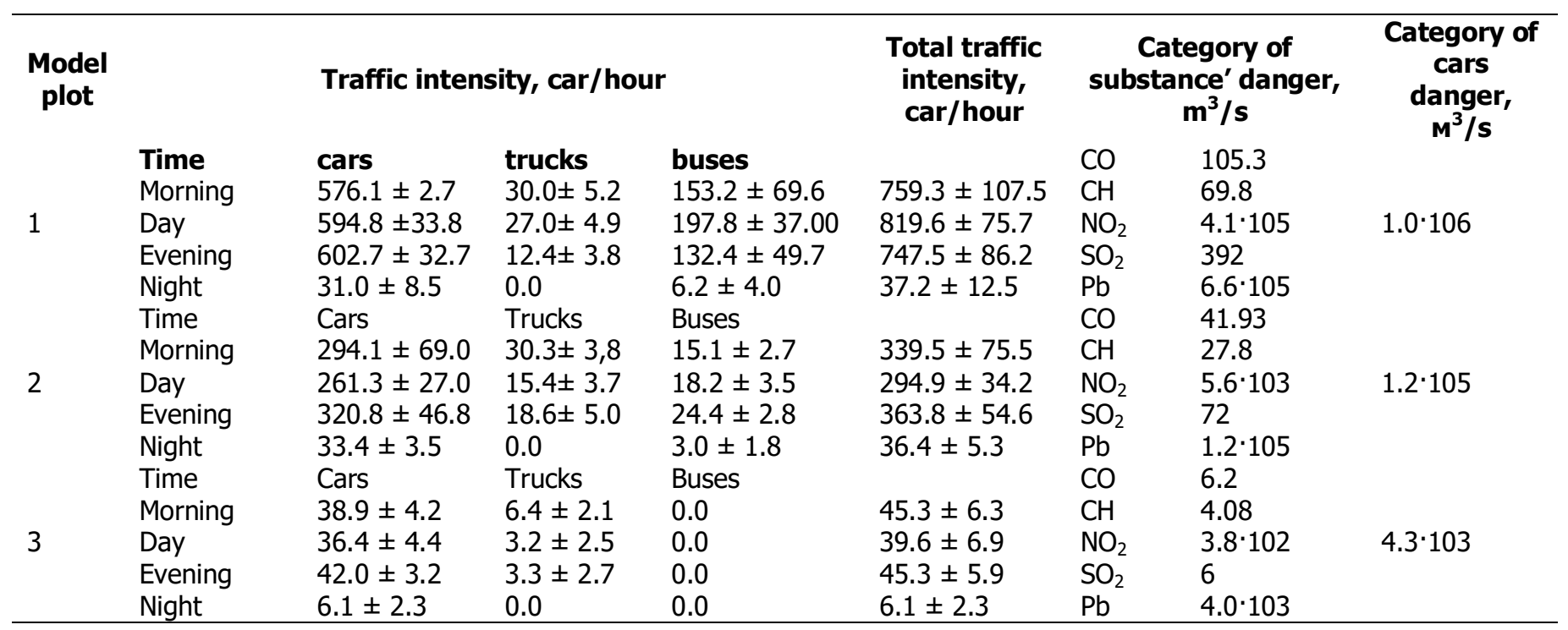

The calculations show that the sample area 1 belongs to Category I dangers factor of roads, phase 2 - Grade II risk, phase 3 danger factor III. Lead and nitrogen oxides have the greatest danger factor of vehicles. The earlier study of soil samples by atomic absorption spectrometry showed that roadside zone areas with high traffic of vehicles undergo a strong burden of toxicant substances exceeding the maximum allowable level. The average concentration of the mobile lead, which is an indicator of soil pollution by vehicle emissions in the city is 2.7 times greater than the background one. The soil of the central and western parts of the city $-12.9 \mathrm{mg} / \mathrm{kg}(6.4 \mathrm{MAC})$ with the most intense traffic belong to the pedogeochemical anomalies. The medicinal dandelion was chosen for the phytoindicative study (Taraxacum officinale Web) - perennial herb of the aster family (Asteraceae). It is a hemicryptophyte. The height of the plant is $5-20 \mathrm{~cm}$. The leaves (up to $20 \mathrm{~cm}$ in length) are collected in the rosette. A cup is modified to hairs, the inflorescence baskets are only ray flowers. Fruit achene fusiform is cylindrical with hairs pappus achene (up to $3 \mathrm{~mm}$ in length). Dandelion medicinal grows in mixed and deciduous forests, as a weed in the areas of forest culture, nurseries, parks and forest parks, can be found on vacant lots near housing, roads, on the edges. Shade tolerant. It blooms from April to July. It is widespread in Ukraine, especially in forest-steppe areas.

\section{Sample selection}

Plants dandelion medicinal was collected at a distance of 5, 10, 15, 20 m from the road (25 plants from each selected point). The collected plants were investigated according to the following indicators: weight of plants; the length of the leaves; abnormal forms proportion; ascorbic acid content; chlorophyll concentration.

\section{Study of the general appearance of plants}

Each plant was weighed, measured the length of the leaves and their number was calculated as a percentage.

The chlorophyll content was determined in $100 \%$ acetone using the Holm-Wettstein method (Musienko et al., 2001). For this purpose, the mass ratio of plant material $(100-200 \mathrm{mg})$ was homogenized in acetone. The obtained extract was passed through a Bunsen flask, poured into a $25 \mathrm{ml}$ volumetric flask, and the volumetric flask was brought to the mark with acetone and used for spectrophotometric determination (Specord 210 Plus) of optical density at various wave lengths: $662 \mathrm{~nm}$ and $644 \mathrm{~nm}$. The pigment content was determined by the formula: Cchl.a+chl.b=5.134-D662+20.436.D644, mg/l dry matter mass. After that, the pigment content is converted to $\mathrm{mg} / \mathrm{g}$ dry matter mass according to the formula:

$$
\mathrm{A}=\frac{\mathrm{C} \cdot \mathrm{V}}{\mathrm{H} \cdot 1000}
$$

where C-pigment concentration, $\mathrm{mg} / \mathrm{l} ; \mathrm{V}$-is the volume of extract, $\mathrm{ml}(25 \mathrm{ml}) ; \mathrm{H}$ - weight of plant material,

To determine the ascorbic acid content, 3-5 g of plant material was homogenized in the presence of $2 \%$ metaphosphoric acid. The filtered extract was divided into three $10 \mathrm{ml}$ samples and $1 \mathrm{ml}$ of a $0.025 \%$ solution of 2,6-dichlorophenoindophenol was added to them. After $35 \mathrm{~s}$, optical density was used for spectrophotometric determination (Specord 210 Plus) at a wave length of $530 \mathrm{~nm}$ against $10 \mathrm{ml}$ of $2 \%$ metaphosphoric acid with $1 \mathrm{ml}$ of $0.025 \%$ 2,6-dichlorophenoindophenol (control). To calculate ascorbic acid, a calibration graph was built. The content of ascorbic acid was determined by the formula:

$$
X=(A \cdot V) / H
$$


where $X$ is the amount of ascorbic acid, $\mathrm{mg} / \mathrm{g}$ wet weight; A-the content of ascorbic acid, $\mu \mathrm{g} / \mathrm{ml}$ extracts found according to the calibration graph; $\mathrm{H}$ is the mass of the sample, $\mathrm{g} ; \mathrm{V}$ is the volume of extract, $\mathrm{ml}$ (Musienko et al., 2001). All experiments were carried out three times. The results are expressed as means \pm SE. The reliability of the difference was evaluated using ANOVA.

\section{Results}

Stressful environmental conditions due to the effect of vehicle emissions, give rise to modified form of the plant dandelion medicinal, namely cause dissection of the leaves. The appearance of modified forms is affected by the intensity of traffic and the distance from the road (Figure 2). The greater the distance from the road the fewer modified forms are. The maximum proportion of the modified forms is observed in the sample area number 1 at a distance of 5 meters from the road and was 20 times greater than in the control area, where the portion of modified forms constitutes only $2 \%$. When the distance from the road was greater the number of modified forms was less (from $40 \%$ to $8 \%$ ). A similar situation was observed in other sample areas, where the portion of modified forms decreased with the distance from the road from $20 \%$ to $10 \%$ (plot № 2) and from $20 \%$ to $8 \%$ (plot № 3 ).

Part of modified
$\quad$ forms, $\%$

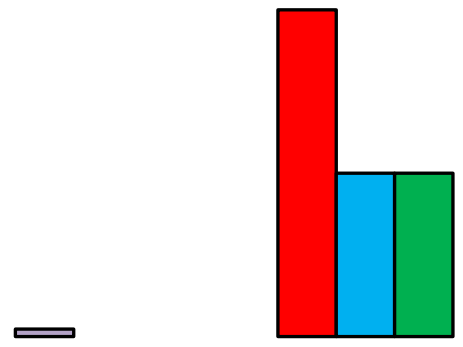

口Model plot №1

口Model plot №2
口Model plot №3
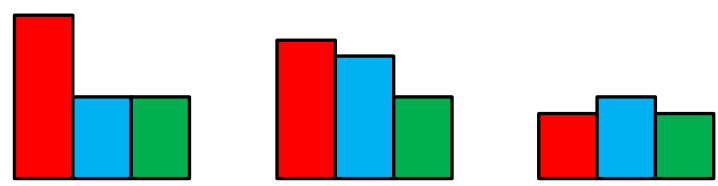

Distance from the road, $\mathrm{m}$

Figure 2. The portion of abnormal forms of dandelion plants on model plots.

Investigation of the plant weight (Table 2) showed that it is slightly reduced on all model plots as compared to the control plot. Reduction of the plant weight, especially of those growing at a distance of 5 meters from the road, indicates the toxic effects of vehicle emissions and results in inhibition of plant growth at a physiological level. The dependence of the plant mass on the distance from the road on plot 1 in the area with the highest density of traffic is clearly seen The mass of plants of plants growing at a distance of 5 meters from the road ranged from $50 \%$ with respect to the weight of control plants, to $71.4 \%$ for plants growing at a distance of $20 \mathrm{~m}$ from the road. There was no dependence on other plots - on plot №2 with an average traffic intensity, the mass varied irregularly - from $53.2 \%$ relative to the weight of control plants at a distance of 10 meters from the road, to $82.1 \%$ for plants growing at a distance of $20 \mathrm{~m}$ from the road. On plot №3 with a minimum traffic, the mass of plants weight also varied unevenly from $54.4 \%$ relative to the weight of control plants at a distance of 5 meters from the road, to $68.6 \%$ in plants growing at a distance of $20 \mathrm{~m}$ from the road. Mass reduction at a distance of 5 meters from the road was observed mainly on plots № 1 and № 3.

Table 2. The weight of dandelion plants on model plots, $(x \pm S E, n=25)$.

\begin{tabular}{llll}
\hline Plots & & Mass of plants, $\mathbf{g}$ & \% relative to the control \\
Control & & $25.2 \pm 6.2$ & 100.0 \\
& $5 \mathrm{~m}$ & $12.6 \pm 2.4$ & 50.0 \\
Plot 1 & $10 \mathrm{~m}$ & $15.2 \pm 3.1$ & 60.3 \\
& $15 \mathrm{~m}$ & $17.3 \pm 2.7$ & 68.6 \\
& $20 \mathrm{~m}$ & $18.0 \pm 3.4$ & 71.4 \\
Plot 2 & $5 \mathrm{~m}$ & $17.3 \pm 1.5$ & 68.6 \\
& $10 \mathrm{~m}$ & $13.4 \pm 1.4$ & 53.2 \\
& $15 \mathrm{~m}$ & $18.3 \pm 4.5$ & 72.6 \\
Plot 3 & $20 \mathrm{~m}$ & $20.7 \pm 5.2$ & 82.1 \\
& $5 \mathrm{~m}$ & $13.7 \pm 2.1$ & 54.4 \\
& $10 \mathrm{~m}$ & $17.3 \pm 2.8$ & 68.6 \\
\hline
\end{tabular}

The analysis of the length of dandelion leaves (Table 3) showed that the maximum length of the leaves of the plant on the control plot was $28.2 \mathrm{~cm}$. The maximum length of leaves on all plots was $69.8-73.0 \%$ relative to the control, and the lowest from $54.2 \%$ for plants from plot № 1 to $73.0 \%$ relative to the control for plants from plot № 2. A clear dependence of the length of leaves on traffic and distance from the road was not observed.

The study showed that the chlorophyll content of plants on all plots is reduced in comparison with the plants in the control group (Table 4). There is an interrelation between the content of chlorophyll and the distance from the road: the greater the distance the higher chlorophyll content. The minimum content of chlorophyll was found in plants growing at a distance of 5 meters from the road on all plots (36.97-53.29\% relative to the control), and the plot with the highest traffic density showed the lowest level $36.97 \%$ relative to the control. The highest chlorophyll content was found in plants growing at a distance of $20 \mathrm{~m}$ from the road 84.10-92.51\% relative to the control. However this chlorophyll content level is less than the one in plants of the control plot. 
Table 3. The length of dandelion leaves on the model plots, $(x \pm S E, n=25)$.

\begin{tabular}{llll}
\hline Plots & & Length of leaves, cm & \% relative to the control \\
Control & & $28.2 \pm 2.4$ & 100.0 \\
& $5 \mathrm{~m}$ & $15.3 \pm 1.2$ & 54.2 \\
Plot 1 & $10 \mathrm{~m}$ & $17.5 \pm 2.4$ & 62.0 \\
& $15 \mathrm{~m}$ & $15.4 \pm 1.3$ & 54.6 \\
& $20 \mathrm{~m}$ & $19.8 \pm 3.5$ & 70.2 \\
Plot 2 & $5 \mathrm{~m}$ & $19.8 \pm 1.7$ & 70.2 \\
& $10 \mathrm{~m}$ & $16.7 \pm 0.9$ & 59.2 \\
& $15 \mathrm{~m}$ & $20.1 \pm 2.2$ & 71.3 \\
Plot 3 & $20 \mathrm{~m}$ & $20.6 \pm 1.8$ & 73.0 \\
& $5 \mathrm{~m}$ & $18.3 \pm 2.0$ & 64.9 \\
& $10 \mathrm{~m}$ & $20.2 \pm 1.9$ & 71.6 \\
\hline
\end{tabular}

Table 4. Chlorophyll content in dandelion on model plots, $(x \pm S E, n=25)$.

\begin{tabular}{llll}
\hline Plots & & $\begin{array}{l}\text { Chlorophyll content (a+B), } \\
\text { mg/g of the dry substance mass } \\
\text { Control }\end{array}$ & $\begin{array}{l}\text { \% relative to the control } \\
\end{array}$ \\
Plot 1 & $5 \mathrm{~m}$ & $1.901 \pm 0.031$ & 100.00 \\
& $10 \mathrm{~m}$ & $2.254 \pm 0.022$ & 36.97 \\
& $15 \mathrm{~m}$ & $2.603 \pm 0.051$ & 45.99 \\
& $20 \mathrm{~m}$ & $4.302 \pm 0.075$ & 53.11 \\
Plot 2 & $5 \mathrm{~m}$ & $1.834 \pm 0.023$ & 87.78 \\
& $10 \mathrm{~m}$ & $2.081 \pm 0.042$ & 37.42 \\
& $15 \mathrm{~m}$ & $3.521 \pm 0.091$ & 42.46 \\
Plot 3 & $20 \mathrm{~m}$ & $4.534 \pm 0.074$ & 71.84 \\
& $5 \mathrm{~m}$ & $2.612 \pm 0.011$ & 92.51 \\
& $10 \mathrm{~m}$ & $3.753 \pm 0.022$ & 53.29 \\
\hline
\end{tabular}

The study of ascorbic acid (AsA) (Table 5) has shown that in all investigated plots the plants that grew in 5 meters from the road had lower content of ascorbic acid $(25.56-44.38 \%$ relative to the control).

Table 5. The ascorbic acid content in dandelion on model plots, $(x \pm S E, n=25)$.

\begin{tabular}{|c|c|c|c|}
\hline Plots & & $\begin{array}{l}\text { Content of ascorbic acid, } \\
\mathrm{mg} / 100 \mathrm{~g} \text { of the damp substance } \\
\text { mass }\end{array}$ & $\%$ relative to the control \\
\hline Control & & $32.51 \pm 0.3$ & 100.00 \\
\hline \multirow{4}{*}{ Plot 1} & $5 \mathrm{~m}$ & $8.31 \pm 0.02$ & 25.56 \\
\hline & $10 \mathrm{~m}$ & $32.38 \pm 0.1$ & 99.60 \\
\hline & $15 \mathrm{~m}$ & $20.33 \pm 0.07$ & 62.55 \\
\hline & $20 \mathrm{~m}$ & $116.57 \pm 0.2$ & 358.57 \\
\hline \multirow{4}{*}{ Plot 2} & $5 \mathrm{~m}$ & $8.32 \pm 0.02$ & 25.58 \\
\hline & $10 \mathrm{~m}$ & $20.33 \pm 0.04$ & 62.55 \\
\hline & $15 \mathrm{~m}$ & $32.77 \pm 0.9$ & 100.80 \\
\hline & $20 \mathrm{~m}$ & $20.36 \pm 0.7$ & 62.64 \\
\hline \multirow{4}{*}{ Plot 3} & $5 \mathrm{~m}$ & $14.42 \pm 0.1$ & 44.38 \\
\hline & $10 \mathrm{~m}$ & $7.12 \pm 0.2$ & 21.91 \\
\hline & $15 \mathrm{~m}$ & $10.78 \pm 0.3$ & 33.17 \\
\hline & $20 \mathrm{~m}$ & $7.66 \pm 0.3$ & 23.58 \\
\hline
\end{tabular}

The analysis of the correlation ratio between morphophysiological factors of a plant, traffic load and the distance from the road (Figure 3) showed that such factors as the average weight of the plants ( $r=0.97)$ on the site with heavy traffic, chlorophyll content $(r=0.92)$ on the same plot, the portion of abnormal forms $(r=-0.94)$ have the closest connection between the traffic load and distance from the road. The correlation coefficient of the portion of abnormal forms is negative because with the distance increase from the road the portion of abnormal forms is reduced. Such factor as chlorophyll content (correlation coefficient ranged from 0.88-0.97) proved the highest dependence. Among the indicators of the length of leaves and the content of vitamin $\mathrm{C}$ there was no clear dependence on the distance from the road. On the trial plot № 1 there was an average relationship between the content of vitamin $\mathrm{C}$ and the distance from the road, the correlation coefficient was 0.82 . On other plots the dependence was discovered to be low. Also, there is no high dependence between the distance from the road and the length of the leaves. 


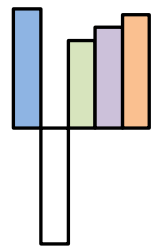

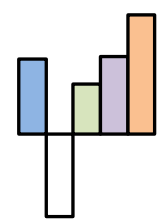

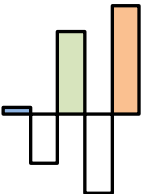

口Mass of plants, $\mathrm{g}$

$\square$ Part of modified forms, \%

口Length of leaves, $\mathrm{cm}$

$\square$ Content ascorbic acid, $\mathrm{mg} / 100 \mathrm{~g}$

$\square$ Content of chlorophills, mg/g

Model plots

Figure 3. The correlation ratio of morphological parameters dandelion with distance from the road.

Table 6 shows the regression models of morphological changes of a dandelion, depending on traffic. The highest coefficients of determination are found in such factors as the chlorophyll content ( $R 2=0.97-0.98)$, the average weight of the plants and the proportion of the most abnormal forms with heavy traffic ( $R 2=0.99$ and $R 2=0.95$, respectively).

Table 6. Regression model of morphophysiological changes of a dandelion. $X$ - distance from the road, $y-$ factors under investigation, $\mathrm{R}^{2}$-coefficient of determination.

\begin{tabular}{llll}
\hline Morphological & Traffic intensity & Regression models & $\mathbf{R}^{\mathbf{2}}$ \\
& Intensive traffic & $\mathrm{y}=63.246 \mathrm{e}-0.1 \mathrm{x}$ & 0.95 \\
Abnormal forms & Medium intensive traffic & $\mathrm{y}=-5.926 \ln (\mathrm{x})+27.995$ & 0.55 \\
& Minimum intensive traffic & $\mathrm{y}=0.08 \times 2-2,72 \mathrm{x}+31$ & 0.92 \\
& Intensive traffic & $\mathrm{y}=-0.19 \times 2+0.841 \mathrm{x}+8.825$ & 0.99 \\
Average weight & Medium intensive traffic & $\mathrm{y}=0.06 \times 2-1.22 \mathrm{x}+21$ & 0.72 \\
& Minimum intensive traffic & $\mathrm{y}=-0.025 \times 2+0.683 \mathrm{x}+11.425$ & 0.27 \\
Leaves length & Intensive traffic & $\mathrm{y}=0.03 \times 2-0.49 \mathrm{x}+17.25$ & 0.64 \\
& Medium intensive traffic & $\mathrm{y}=0.033 \times 2-0.723 \mathrm{x}+22.175$ & 0.54 \\
Chlorophyll content & Minimum intensive traffic & $\mathrm{y}=16.536 \times 0.0628$ & 0.56 \\
& Intensive traffic & $\mathrm{y}=0.0126 \times 2-0.1586 \mathrm{x}+2.36$ & 0.97 \\
Ascorbic acid content & Medium intensive traffic & $\mathrm{y}=0.0075 \times 2+0.0011 \mathrm{x}+1.5575$ & 0.97 \\
& Minimum intensive traffic & $\mathrm{y}=-0.0105 \times 2+0.3575 \mathrm{x}+1,112$ & 0.98 \\
& Intensive traffic & $\mathrm{y}=0.0557 \times 2-0.9095 \mathrm{x}+4.3525$ & 0.86 \\
& Medium intensive traffic & $\mathrm{y}=-0.0186 \times 2+0.5394 \mathrm{x}-1.685$ & 0.90 \\
& Minimum intensive traffic & $\mathrm{y}=0.0032 \times 2-0.1056 \mathrm{x}+1.49$ & 0.54 \\
\hline
\end{tabular}

\section{Discussion}

In 2018, 24.4 thousand tons of pollutants from stationary sources were thrown into the air basin of the city of Cherkasy. A significant contribution to air pollution is made by motor vehicles (52\% in 2015). In 2018, the atmospheric pollution index was 6.24, which corresponds to an increased level of atmospheric air pollution (Regional'na dopovid', 2018). Analysis of the weather conditions shows that the processes of accumulation of contaminants prevails over the dissipate process, resulting in aerotehnogenic pollution of the city environment. Under the influence of increasing anthropogenic load in Cherkassy the functioning of ecosystems is ruined. Most of the green spaces of the city, especially the southern and north-eastern parts have unsatisfactory condition. Characteristic lesions of plants: ulcer (all species), tumor (balsam poplar, chestnut plain, lime), wet Bacteriosis (ash, chestnut plain), scaly bark peeling (brown ordinary). $60 \%$ of leaves in the trees have point and edge necrosis. $80 \%$ of poplar trunks have ulcers. Poplar sparse crown ranges from 40 to $90 \%$. In the southeastern part of the city the state of ordinary brown chestnut and robinia are in a poor condition. Up to $50 \%$ of the surface of leaves is damaged by the necrosis. Crown thinning constitutes $40 \%$. Basically leaves are wrecked with brown spots (up to $20 \%$ ). There is an increase of dry branches of the 1-3-th order in $30 \%$ of plants (Chemerys et al., 2013). There is a well-known classification of damage phytostromy, which reflects the dynamics of the gas influence on plants invisible injury, chronic damage, acute (catastrophic) damage. There are following morphological changes developing in plants under the influence of phytotoxicants at the organism level: chlorosis and necrosis appear on the leaves, premature aging. The processes of inhibition of plant growth and violation of the formation of generative organs are explained by the penetration of phytotoxicants into the merisystem and also by the depression of photosynthesis. The reason for the formation of necrosis is photodynamic and free radical oxidation as well as chemical poisoning of cells by high concentrations of toxic compounds. It has been shown that plants can accumulate heavy metals in their leaves, in particular lead (Youssef et al., 2014). In gas mixtures nitrogen oxides synergistically enhance the phyto-toxicity of sulfur oxide (IV). In the study of herbaceous plants synergies manifested in reduction of the growth of grasses, their total dry weight, number of leaves, shoots, leaf area and mass of roots. Plants during flowering and early fruit formation are most sensitive to aero-pollutants. Thus, phytotoxicants have local impact and moving through the plant, cause secondary changes. In Figure 4 presents a diagram of macroscopic changes that break out under the influence of toxicants. 


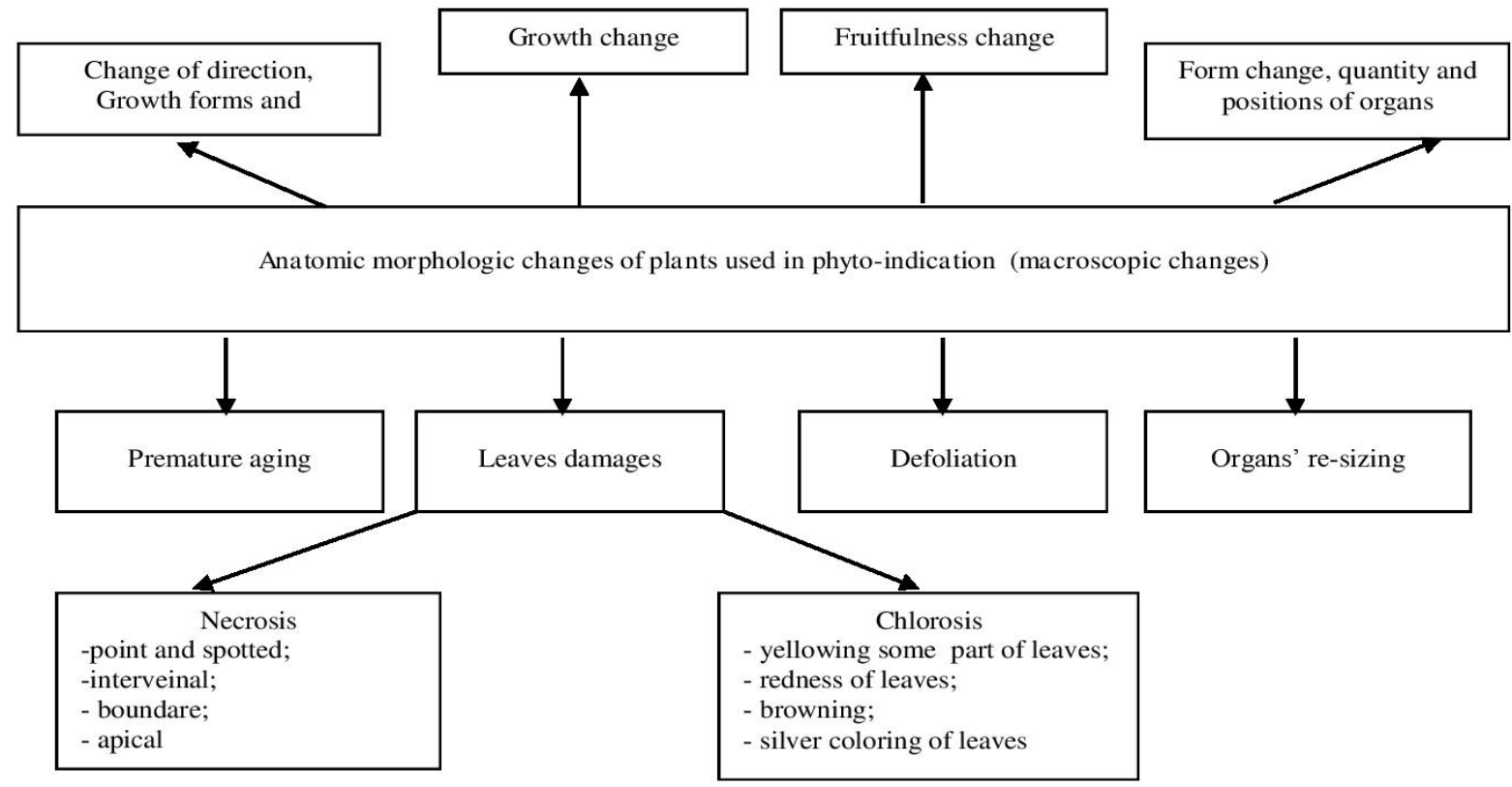

Figure 4. Schematic diagram of the macroscopic changes developing under the influence of toxicants (Chemerys \&Hryb, 2005).

The effect of automobile transport can be classified as chronic. With this action, plant growth is sharply inhibited, the number of leaves decreases, chlorosis develops, and in the second half of the growing season apical or marginal necrosis appears, and the proportion of non-viable seeds increases (Chemerys, I. et al., 2009, 2013). It should be noted that in urban environments, there is a change in the morphological parameters of the leaf blade (Wen-yi \& Chun-kui, 2012; Tyulkova, 2015). For dandelion officinalis, a non-uniformly pinnate or dissected leaf blade is characteristic (Azkhnagulova et al., 2014). As for the abnormal forms of the leaf blade, in particular, their excessive dissection, Sanchez, 1967, showed that the greater the illumination of plants, the more the dissected blade, and a decrease in illumination leads to a rounding of the leaf shape. It is also noted that, possibly, the temperature conditions also affect the shape of the leaf blade, which together with the action of light lead to a change in the synthesis of a number of enzymes, which leads to a change in the shape of the leaf blade. In studies, it was noted that the effect of radiation exposure causes the death of somatic cells and slows down the growth rate. Mismatch of tissue growth rates leads to the formation of altered forms of dandelion leaf blades, since changes in the genome do not always cause cell death and modified cells form a changed tissue during division (Pozolotina, 2003). Since there are also mutagens in motor vehicle emissions, it can be assumed that, like physical mutagens, they cause the development of abnormal forms of leaf blades. Thus, our studies have shown that the presence of altered forms is affected by the intensity of traffic and distance from the road. With increasing distance from the road, the proportion of altered forms decreases (in the area with the most intensive traffic from $40 \%$ to $8 \%$ ).

It was also shown that, with an increase in aerotechnogenic load, the sizes and leaf blades of woody plants decrease, but the influence of meteorological factors on these parameters is also noted (Ianovici, 2016). Our studies of leaf lengths showed that there was no clear dependence of leaf length on traffic intensity and distance from the road. In the area with the average traffic intensity, the correlation coefficient was 0.41 , while in the areas with high traffic intensity and low traffic intensity, it was 0.71 and 0.67 , respectively. The results of studies correlate with Balasooriya et al. (2009), that indicated a small potential of the morphological parameters of dandelion leaves. Thus, we can conclude that a number of abiotic factors that were not taken into account in the studies, both meteorological and edaphic factors, influenced the length of the leaves.

The study of plant mass showed that only in the area with a high intensity of traffic (plot № 1) is there a relationship between the mass of plants and the intensity of movement $(r=0.97)$, while in areas with an average intensity of movement $r=0.61$, and with a low $r=0.55$. Our results are confirmed by studies by (Ianovici, 2016), in which it is shown that dandelion is an indicator of the concentration of heavy metals in the immediate vicinity of a road with heavy traffic.

The most vulnerable cell structures are chloroplasts. Due to the action of aerotoxicants in chloroplasts, the processes of photosynthesis are suppressed, chlorophylls are destroyed and their synthesis is disturbed. The main sign of gas and smoke stress in a plant cell is a decrease in the content of chlorophylls, an increase in the content of AsA as a stress resistance factor (El-Khatib et al., 2016). Stressful conditions reduce the synthesis of chlorophylls (Ashraf \& Harris, 2013). Aeropollutants accumulate in chloroplasts, which changes their structure, therefore photosynthesis is suppressed, pigments are destroyed and chlorophyll is converted into pheophytin. Chlorophyll synthesis is also reduced. Low concentrations of toxic gases cause a slow decrease in the intensity of photosynthesis, since they inhibit the formation of chloroplasts, the biosynthesis of pigments and their functional activity, and high ones - a rapid inhibition of photosynthesis. The influence of vehicles leads to the accumulation of heavy metals in soils and T. officinale is a bioindicator of soil pollution with heavy metals (Ligocki et al., 2011; Giacomino et al., 2016; Fröhlichová et al., 2018). An inverse correlation was found between the concentrations of chlorophyll and Cd in shoots (Bini et al., 2012). Raina \& Chand Bala, 2011 and El-Khatib et al., 2016 indicate a decrease in the chlorophyll content in the leaves of herbaceous plants with an increase in traffic flow. We found that with an increase in the distance from the road and a decrease in traffic intensity, the chlorophyll content increases (correlation coefficient in different areas ranged from 0.88-0.98), and the chlorophyll content in areas with heavy and medium traffic in the maximum proximity to the road $(5 \mathrm{~m})$ was only one third of the chlorophyll content in plants of the control site. At a distance of $20 \mathrm{~m}$ from the road in all sections, the chlorophyll content approached the chlorophyll content in control plants $(81.6-92.51 \%)$. AsA is used to modulate a number of fundamental functions in plants, both under stress and in the absence of stress (Akram et al., 2017), serves as the main redox buffer and regulates various physiological processes that control growth, development, and stress resistance. (Hossain et al., 2017). Excessive production of reactive oxygen species (ROS) in plants 
under stress is common and AsA is one of the universal non-enzymatic antioxidants that has significant potential not only to remove ROS, but also to modulate a number of fundamental functions in plants both under stress and in the absence of stress (Akram et al., 2017). Therefore, the accumulation of ascorbic acid can be an indicator of stress due to abiotic factors. An inverse correlation was observed between the lead content in the soil and antioxidant activity (Samancioglu et al., 2016; Maslennikov et al., 2018). It has also been shown that under the influence of automobile emissions, an inverse correlation is observed between the chlorophyll $b$ content and the AsA content (Raina \& Chand Bala, 2011; Iqbal et al., 2015; Zhou et al., 2018).

Our studies showed that the highest concentration of AsA was recorded in plants that grew at a distance of $20 \mathrm{~m}$ from the road in the area with the most intense traffic ( 3.6 times higher than that of plants in the control plot). Such a high concentration can be explained by the adaptation of plants to the action of toxicants, and in plants growing closer than $20 \mathrm{~m}$ to the road, lower concentrations of AsA are explained by the suppression of anti-stress mechanisms. In sample plot № 3, the content of vitamin C at a distance of $5 \mathrm{~m}$ (44.38\% relative to the control) from the road is higher than at other distances (21.91-33.17\% relative to the control), which can be explained by the influence of additional factors that were not considered in the experiment, for example, moisture and soil type. In addition to these factors, the factor of the depressed state of plants during the period of their collection could affect the AsA content, that is, the neutralization of harmful emissions from vehicles has not yet taken place and vitamin $\mathrm{C}$ has not accumulated. Thus, the indicator of the content of vitamin $\mathrm{C}$ showed a lack of information.

Thus, it should be noted that the issue of changing the physiological functions of a dandelion under the influence of traffic is an insufficiently studied issue, since these functions are also affected by natural factors, such as lighting, soil moisture, temperature, and wind. And therefore, in further studies it is important to highlight the degree of influence of natural factors and motor load to determine the role of dandelion as a biomonitor of vehicle emissions.

\section{Conclusion}

As a result of research of the morphological and physiological characteristics of medicinal dandelion under the influence of vehicle emissions with a view to a comprehensive diagnosis of the state of the urbanized ecosystems following results were obtained:

The test plants are under stress due to the toxic effect of vehicle emissions. The factor of the proportion of abnormal forms, in particular cut leaves shows the stressful conditions. The plants, growing beside the road have the greater proportion of abnormal forms (up to $40 \%$ of the plants that grow in 5 and 15 meters from the road), on the control plots this percentage is very low ( $2 \%$ ). Also, plants have a reduced mass and the length of the leaves on all plots. The greatest decrease in these factors compared to the control was observed on the plot with heavy traffic at a distance of 5 and 10 meters from the road.

Changes of morphometric and physiological parameters of the test plants are caused by a complex effect of emissions from motor vehicles, which have both direct and indirect effects leading to such changes as changes of their size, weight, chlorophyll contents. Chlorophyll synthesis changes are evoked by disorders of mineral nutrition of plants due to the absorption of nitrogen oxides and sulfur soils (indirect impact of vehicles). Sulfur and nitrogen oxides contained in the emissions of vehicles also influence the chlorophyll content. Heavy metals, such as lead, which is accumulated in soils inhibit the growth, cause the appearance of abnormal forms (cut leaves). The most informative phytoindicators of dandelion medicinal appeared to be: the portion of abnormal forms, the average weight of plants, chlorophyll content. It is between these parameters and the distance from the road there is a clear relationship, as evidenced by high correlation coefficients. Length of leaves and the content of vitamin $\mathrm{C}$ were less informative, because there is no clear relationship between these indicators and the distance from the road.

The amount of chlorophyll is affected by the traffic load, consequently the lowest chlorophyll content was observed on plot № 1 , with the most intensive traffic, and the highest rate of chlorophyll content was observed on plot №3, with the lowest traffic intensity, but still all plots had lower figures than control plot by 2.5 times. Chlorophyll content increases with the increasing distance from the road. By reducing the content of chlorophyll photosynthesis of plants deteriorates, resulting in reduced weight, growth and development of plants. Increased levels of vitamin C are due to the fact that it is an antioxidant, so stressful conditions are helpful to dandelion to adapt to the harmful effects of vehicle emissions. Various physiological and biochemical and anatomicmorphological mechanisms are involved in the plant adaptation to the environment. In particular this applies to the intensities of different processes such as photosynthesis and pigment content. Study of features of the pigment apparatus of plants with different tolerance is of great importance for elucidating the mechanisms of a plant adaptation to the existence conditions according to the plants stress resistance and requires further research. Further developments include clarification of the information content of the content factor of ascorbic acid to be used to display the invisible changes of vegetation cover.

\section{References}

Aksu, A. (2015). Sources of metal pollution in the urban atmosphere (A case study: Tuzla, Istabul). Journal of Environmental Health Science and Engineering, 13 (1), 79. DOI: 10.1186/s40201-015-0224-9.

Ashraf, M., Harris, P.J.C. (2013). Photosynthesis under stressful environments: An overview. Photosynthetica, 51(2), 163-190. DOI: 10.1007/s11099-013-0021-6.

Assadi, A., Pirbalouti, A., Malekpoor, F., Teimori, N., Assadi, L. (2011). Impact of air pollution on physiological and morphological characteristics of Eucalyptus camaldulensis Den. Journal of Food, Agriculture and Environment, 9, 676-679. DOI:10.1234/4.2011.2188.

Akram, N.A., Shafiq, F., M.Ashraf. (2017). Ascorbic Acid-A Potential Oxidant Scavenger and Its Role in Plant Development and Abiotic Stress Tolerance. Frontiers in Plant Science, 8, 613. DOI:10.3389/fpls.2017.00613.

Alamri, S.A., Siddiqui, M.H., Al-Khaishany, M.Y., Khan, M.N., Ali, H.M., Alaraidh, I.A., Alsahli, A.A., Al-Rabiah H., Mateen M. (2017). Ascorbic acid improves the tolerance of wheat plants to lead toxicity. Journal of Plant Interactions, 13 (1). Retrieved from https://www.ncbi.nlm.nih.gov/pmc/articles/PMC5405147/. DOI:10.1080/17429145.2018.1491067.

Aznagulova, A.V., Kurkin, V. A., Ryzhov, V. M., Tarasenko, L.V. (2014). Anatomo-morfologicheskoe issledovanie nadzemnoj chasti oduvanchika lekarstvennogo (Taraxacum Officinale Wigg.) [Anatomical and morphological study of the aerial part of dandelion ( Taraxacum Officinale Wigg.)]. Medicinskij almanah, 3 (33), 173-179 (In Russian).

Balasooriya, B., Samson, R., Mbikwa, F., Vitharana, U., Boeckx, P., Meirvenne, M. (2009). Biomonitoring of urban habitat by anatomical and chemical leaf characteristics. Environmental and Experimental Botany, 65(2-3), 386-394. DOI:/10.1016/j.

Bell, J.N., Honour, S.L., Power, S.A.(2011). Effects of vehicle exhaust emissions on urban wild plant species. Environmental Pollution, 159(8-9),1984-90. DOI: 10.1016/j.envpol.2011.03.006.

Bessonova, V. P., Ponomaryova, O. A. (2017). Morphometric characteristics and the content of plastid pigments of the needles of Picea pungens depending on the distance from the highways. Biosystems Diversity, 25(2), 96-101. DOI:10.15421/011714. 
Bini C., Wahsha M., Fontana S., Maleci L. (2012). Effects of heavy metals on morphological characteristics of Taraxacum officinale Web growing on mine soils in NE Italy. Journal of geochemical exploration, 123, 101-108. DOI: 10.1016/j.gexplo.2012.07.009.

Chemerys, I., Hryb, Y. (2005). Ekolohichna otsinka stanu navkolyshn'oho seredovyshcha metodamy fitoindykatsiyi [Environmental assessment of the state of the environment by phytoindication methods]. Visnyk Natsional'noho universytetu vodnoho hospodarstva ta pryrodokorystuvannya, 1 (29), 3-11(in Ukrainian).

Chemerys, I., Zrazhevs'kyy, S. (2009). Vplyv vidprats'ovanykh haziv avtotransportu na fotosyntetychnu funktsiyu roslyn [Effect of vehicle exhaust on the photosynthetic function of plants]. Pytannya bioindykatsiyi ta ekolohiyi, 14 (2), 86-100 (in Ukrainian).

Chemerys, I., Zahoruyko, N., Konyakin S.M. (2013). Fitomonitorynh vykydiv avtotransportu v umovakh mis'koho seredovyshcha [Phytomonitoring of vehicle emissions in urban environment]. Lyudyna i dovkillya: problemy neoekolohiyi, 3-4, 141-146 (in Ukrainian).

Dániel, P., Kovács, B., Prokisch, J., Gyõri, Z. (1997). Heavy metal dispersion detected in soils and plants alongside roads in Hungary. Chemical Speciation \& Bioavailability, 9(3), 83-93. DOI: 10.1080/09542299.1997.11083292.

Dolatabadian, A., Jouneghani, R.S. (2009). Impact of Exogenous Ascorbic Acid on Antioxidant Activity and Some Physiological Traits of Common Bean Subjected to Salinity Stress. Notulae Botanicae Horti Agrobotanici Cluj-Napoca 37 (2), $165-172$. DOI:10.15835/nbha3723406.

El-Khatib, A.A., El-Shanawany, A.A., El-Amery, E.M. (2016). Urban tree leaf as bio-indicator for air pollution around superphosphate fertilizers plant, Upper Egypt. Journal of Ecology of Health \& Environment An International Journal, 4 (2), 95-101. DOI:10.18576/jehe/040207.

Erofeeva, E.A. (2014). Dependence of dandelion (Taraxacum officinale Wigg.) seed reproduction indices on intensity of motor traffic pollution. Dose Response, 12(4), 540-550. DOI: 10.2203/dose-response.14-009.

Fröhlichová, A., Száková, J., Najmanová, J., \& Tlustoš, P. (2018). An assessment of the risk of element contamination of urban and industrial areas using Taraxacum sect. Ruderalia as a bioindicator. Environmental Monitoring and Assessment, 190(3), 150. DOI: 10.1007/s10661-018-6547-0.

Gaırca-Gil, J.C., Plaza C., Soler-Rovira P., \& Polo A. (2000). Long-term effects of municipal solid waste compost application on soil enzyme activities and microbial biomass. Soil Biology \& Biochemistry, 32, 1907-1913. DOI:10.1016/S0038-0717(00)00165-6.

Giacomino, A., Malandrino, M., Colombo, M.L., Miaglia, S., Maimone, P., Blancato, S., Conca, E., Abollino O. (2016). Metal content in dandelion (Taraxacum officinale) leaves: influence of vehicular traffic and safety upon consumption as food. Journal of Chemistry, 2016. Retrieved from https://www.hindawi.com/journals/jchem/2016/9842987/ DOI:10.1155/2016/9842987.

Gupta, B., Huang, B. (2014). Mechanism of Salinity Tolerance in Plants: Physiological, Biochemical, and Molecular Characterization. Internftional Journal of Genomics,1, 1-18. DOI: 10.1155/2014/701596.

Hossain, M.A., Munné-Bosch, S., Burritt, D.J., Diaz-Vivancos, P., Fujita, M., Lorence A. (2017). Ascorbic Acid in Plant Growth, Development and Stress Tolerance. DOI:10.1007/978-3-319-74057-7.

Ianovici, N. (2016). Taraxacum officinale (Asteraceae) in the urban environment: seasonal fluctuations of plant traits and their relationship with meteorological factors. Acta Agrobotanica, $69 \quad$ (3). Retrieved from https://pbsociety.org.pl/journals/index.php/aa/issue/view/482/showToc. DOI:10.5586/aa.1677.

Iqbal, M.Z., Shafig, M., Zaidi, S.Q., Athar M. (2015). Effect of automobile pollution on chlorophyll content of roadside urban trees. Global journal of environmental science and management publication, 1(4), 283-296. DOI: 10.7508/gjesm.2015.04.003.

Kabata-Pendias, A. (2011). Trace Elements in Soil and Plants. CRC Press, Boca Raton, FL.

Kabata-Pendias, A., Dudka, S. (1991).Trace metal contents of Taraxacum officinale (dandelion) as a convenient environmental indicator. Environmental geochemistry and health, 13 (2), 108-130. DOI: 10.1007/BF01734301.

Keane, B., Collier, M.H., Rogstad, S.H. (2005) Pollution and genetic structure of North American populations of the common dandelion (Taraxacum officinale). Environmental Monitoring and Assessment, 105(1-3), 341-357. DOI:10.1007/s10661-005-4333-2. Khan, T.A., Mazid, M., Mohammad F. (2011). A review of ascorbic acid potentialities against oxidative stress induced in plants, Journal of agrobiology, 28(2), 97-111. DOI: 10.2478/v10146-011-0011-x.

Kováčik, J., Dudáš, M., Hedbavny, J., Mártonfi, P. (2016). Dandelion Taraxacum linearisquameum does not reflect soil metal content in urban localities. Environmental pollution, 218, 160-167. DOI: 10.1016/j.envpol.2016.08.030.

Kudryavs'ka, T.B., Dychko, A.O. (2014). Metod ocenki i prognozirovaniya vliyaniya tehnogennogo zagryazneniya na vozduh urboe 'kosistemy [Method for assessing and predicting the impact of industrial pollution on the air of urban ecosystems]. Vostochnoevropeyskiy zhurnal peredovyh tehnologiy. T.1, 10 (67 ), 4-7. DOI: 10.15587/1729-4061.2014.19882 (In Russian).

Kolesnikov, S., Kazeev, K., Val'kov, V. (2001). Biojekologicheskie principy monitoringa i normirovanija zagrjaznenija pochv [Bioecological principles of monitoring and regulation of soil pollution]. CVRR, Rostov-n/D. (In Russian).

Labuzova O.M., Noskova T.V., Lysenko M.S., Ilina E.G. (2016). Ekoanaliticheskij kontrol i bioindikaciya sostoyaniya gorodskoj territorii [Ecological control and bioindication of urban area]. Acta Biologica Sibirica, 2(3), 21-24. DOI: 10.14258/abs.v2i3.1451 (In Russian).

Ligocki, M., Tarasewicz, Z., Zygmunt, A., Aniśko, M. (2011). The common dandelion (Taraxacum officinale) as an indicator of anthropogenic toxic metal pollution of environment. Acta Scientiarum Polonorum. Zootechnica, 10 (4), 73-82.

Lugovskaya, A.Yu., Khramova, E.P., Trubina, L.K. (2014). Effect of transport and industrial pollution on morphological and biochemical parameters of Potentilla fruticosa (Rosaceae). Rastitel `nyy mir aziatskoy Rossii, 1, 71-76.

Maslennikov, P.V., Chupakhina, G.N., Skrypnik, L.N., Feduraev, P.V., Melnik, A.S. (2018). Assessment of the Antioxidant Potential of Plants in Urban Ecosystems under Conditions of Anthropogenic Pollution of Soils. Russian Journal of Ecology. Vo. 49, 5, 384-394. DOI: $10.1134 / S 1067413618050065$.

Maslennikov, P.V., Chupakhina, G.N., Skrypnik, L.N., Feduraev P.V., Melnik, A.S. (2018). The contribution of polyphenols to plantresistance to $\mathrm{Pb}$ soil pollution. International Journal of Environmental Studies, 75 (5), 719-731. DOI: 10.1080/00207233.2018.1440816.

Markert, B., Wünschmann, S., Baltrènaitè E. (2012). Innovative observation of the environment. Bioindicators and biomonitors: definitions, strategies and applications. Journal of Environmental Engineering and Landscape Management, 20 (3), 221-239. DOI: $10.3846 / 16486897.2011 .633338$

Mikalajūnè, A., Jakučionytė, L. (2011). Investigation into heavy metal concentration by the gravel roadsides. Journal of Environmental Engineering and Landscape Management, 19 (1), 89-100. DOI: 10.3846/16486897.2011.557474 
Musiyenko, M.M., Parshikova, T.V., \& Slavnij, P.S. (2001). Spektrofotometrichni metodi v praktici fiziologiyi, biohimii ta ekologiyi roslin [Spectrophotometric methods in the practice of physiology, biochemistry and plant ecology]. Phytosociocenter, Kyev (in Ukrainian).

Myslyuk, O., Myslyuk, Ye., Solomka, L. (2010). Otsinka vplyvu vykydiv Cherkas'koyi TETs na stan urbolandshaftiv [Assessment of the impact of Cherkasy HEP emissions on the state of urban landscaping]. Visnyk ONU. Khimiya. Vo.15 (12-13), 47-53 (in Ukrainian).

Myslyuk, O., Khomenko, O., Yehorova, O. (2019). Ekologichna ocinka kislotno-osnovnih vlastivostej urbozemiv m. Cherkasi [Ecological as sessment for the acid-base properties of urban soils in Cherkasy city]. Transactions of Kremenchuk Mychailo Ostrohradskyi National University, 4, 117. DOI: 10.30929/1995-0519.2019.4.53-59/ (in Ukrainian).

Myslyuk O., Khomenko O., Yehorova O., Pydorenko V. (2019). Ekologichni aspekti stanu urbozemiv [Environmental aspects of urban soils]. Visnyk Cherkaskogo derzhavnogo technolohichnogo universytetu. Seria: Tehnichni nauky, 2, 123-133. DOI: 10.24025/23064412.2.2019.172233) (in Ukrainian).

Nagajyoti, P.C., Lee, K. D., Sreekanth, T.V.M. (2010). Heavy metals, occurrence and toxicity for plants: a review. Environmental Chemistry Letters, 8, 199-216. DOI:10.1007/s10311-010-0297-8.

Nersisyan, G. S., Hovhannisyan H. A. (2010). Application of Phytoindication Method for Controlling Air Pollution in Yerevan. Armenia. Journal of Life Sciences, Vo. 4, 4 (29), 52-57. DOI:10.17265/1934-7391/2010.06.010.

Normandin, L., Kennedy, G., Zayed, J. (1999). Potential of dandelion (Taraxacum officinale) as a bioindicator of manganese arising from the use of methylcyclopentadienyl manganese tricarbonyl in unleaded gasoline. Science of the total environment, 239(1-3), 165-71. DOI:10.1016/s0048-9697(99)00292-2.

Pehlivan, F.E. (2017). Vitamin C: An Antioxidant Agent. Retrieved from https://www.intechopen.com/books/vitamin-c/vitamin-c-anantioxidant-agent. DOI: 10.5772/intechopen.69660.

Pozolotina, V.N. (2003). Otdalennye posledstviya dejstviya radiacii na rasteniya [Longterm effects of radiation on plants]. Akademkniga, Ekaterinburg (In Russian).

Raina, A.K., Chand Bala (2011). Effect of vehicular pollution on Duranta repens L. in Jammu City. Journal of Applied and Natural Science 3 (2), 211-218. DOI:10.31018/jans.v3i2.181.

Regional'na dopovid' pro stan navkolyshn'ogo pryrodnogo seredovyshha v Cherkas'kij oblasti u 2018 roci [Regional report on the state of the environment in Cherkasy region in 2018] (2019). Cherkassy (in Ukrainian).

Samancioglu, A., Sat, I.G., Yildirim, E. (2016). Total phenolic and vitamin C content and antiradical activity evaluation of traditionally consumed wild edible vegetables from Turkey. Indian Journal of Traditional Knowledge, 15 (2), $208-213$. DOI:10.1080/01448765.2013.827992.

Sanchez, R.A. (1967). Some Observations about the Effect of Light on the Leaf Shape in Taraxacum Officinale L. Retrieved from http://edepot.wur.nl/299514.

Simon, L., Martin, H.W., Adriano D.C. (1996). Chicory (Cichorium intybus L.) and dandelion (Taraxacum officinale Web.) as phytoindicators of cadmium contamination. Water, Air, and Soil Pollution, 91, 351-362. DOI:10.1007/bf00666269.

Smirnoff, N. (2018). Ascorbic acid metabolism and functions: A comparison of plants and mammals. Free Radical Biology \& Medicine, 122, 116-129. DOI: 10.1016/j.freeradbiomed.2018.03.033.

Smirnoff, N., Wheeler, G.L. (2000). Ascorbic acid in plants: biosynthesis and function. Critical Reviews in Biochemistry and Molecular Biology, 35(4), 291-314. DOI: 10.1080/10409230008984166.

Spencer, H.J., Scott, N.E., Port G.R., Davison A.W. (1988). Effects of roadside conditions on plants and insects. I. Atmospheric conditions. Journal of applied ecology, 25 (2), 699-707. DOI: 10.2307/2403855.

Tesliyk, A. A. (2017). Environmental Assessment of the State of Atmospheric Air of Commercial Holdings by Bioindicating Methods. Scientific Bulletin of UNFU, 27(6), 85-88. DOI: 10.15421/40270617.

Tsandekova, O.L., Neverova, O.A., Kolmogorova, E.Yu. (2013) The role of antioxidant system in the stability of pine stands on a coal spoil bank. Izvestiya Samarskogo nauchnogo centra Rossiyskoy akademii nauk, 15 (3), 559-562.

Tyulkova, E.G. (2015) Morphological parameters leaves woody plants in an urban environment (on Gomel example). Ecology and noospherology. Vo. 26, 3-4, 62-71. DOI: 10.15421/031520.

Wen-yi, Qu, Chun-kui, Hu (2012). Xibei nonglin keji daxue xuebao. Ziran kexue ban [Contact colors of the leaves of plants and ecological parameters of the environment, specifies a method for wireless communications]. Jornal Northwest A\&F University Natural Science, 7, 221-228 (in Chinese).

Wilson, M.A., Burt, R., Indorante, S.J., Jenkins, A.B., Chiaretti, J.V., Ulmer, M.G., Scheyer J.M. (2008). Geochemistry in the modern soil survey program. Environment Monitoring Assessment, 139, 151-171. DOI:10.1007/s10661-007-9822-z.

Youssef, N., Markert B., Gurbanov, E., Sevnic, H., Wünschmann, S. (2014). Bioindication of trace metal pollution in the atmosphere of Baku city using ligustrum japonicum, olea europea, and pyracantha coccinea leaves. Journal of Environmental Engineering and Landscape Management, 22 (1), 14-20. DOI:10.3846/16486897.2013.804828.

Zhang, F., Yan, X., Zeng, C., Zhang, M., Shrestha, S., Devkota, L.P., Yao, T. (2012). Influence of Traffic Activity on Heavy Metal Concentrations of Roadside Farmland Soil in Mountainous Areas. International journal of environmental research and public health, 9, 1715-1731. DOI:10.3390/ijerph9051715.

Zhou X., Sun, C., Zhu, P., F, Liu. (2018). Effects of Antimony Stress on Photosynthesis and Growth of Acorus calamus. Frontiers in Plant Science, 9, 579. DOI: 10.3389/fpls.2018.00579.

\section{Citation:}

Chemerys, I., Myslyuk, O., Chemerys, V. (2020). Effect of vehicle emissions on the morphological and physiological changes of Taraxacum officinale web. Ukrainian Journal of Ecology, 10(1), 7-17.

This work is licensed under a Creative Commons Attribution 4.0. License 